Pteridines

Vol. 5, 1994, pp. $107-110$

\title{
Effect of Folate-deficient Diet and 5-Fluorouracil Treatment in the in vivo Model of Mice L1210 Leukemia
}

\author{
Julita Graczyk \\ Department of Pharmacology, Medical University of Lódź, Poland.
}

(Received April 18, 1994)

\section{Summary}

The present study investigated the effect of reduced folic acid content in the organism, due to deficient diet, on the survival time of mice with L1210 leukemia, treated with fluorouracil. One of the mechanisms of the cytotoxic effect of fluorouracil is the inhibition of thymidylate synthase by binding fluorodeoxyuridylate, a 5-fluorouracil metabolite. Tetrahydrofoliane factor, for which folic acid is the substrate, takes part in this process. From the presented study it follows that the synthetic diet prepared without the addition of folic acid caused significantly lower blood serum folic acid levels, reduction of vitamin $\mathrm{B}_{12}$ level, anemia, as well as lowered leukocyte count. The antineoplastic effect of fluorouracil on L1210 leukemia was in that group of mice weaker than the effect of fluorouracil in mice receiving synthetic diet which met their folic acid requirement.

Key words : 5-fluorouracil, Mice L1210 leukemia, Experiment in vivo, Folic acid deficiency, Synthetic diets

\section{Introduction}

5-Fluorouracil is among the most effective drugs in the treatment of adenocarcinomas of the gastrointestinal tract, breast cancer and squamous cell carcinoma of the head and neck (1). FU may also be converted by appropriate modulation to an active drug in neoplasms in which they have little or no single agent activity : leukemias, lymphomas. In vitro studies have shown marked potentation of FU cytotoxicity by methotrexate as well as by folates against a human lymphoblastic leukemia cell line CCRFCEM (2). Antineoplastic activity of FU is complex; one of the mechanisms of the cytotoxic effect of the drug is the inhibition of thymidylate synthase by binding FdUMP, FU metabolite. Tetrahydrofoliane cofactor, 5, 10-methylenetetrahydrofolate, for which fol-

\footnotetext{
Abbreviations

FU-fluorouracil, FdUMP-fluorodeoxyuridine monophosphate, FUTP-fluorouridine triphosphate, dTMP-thymidine monophosphate, MST-median survival time, ILS\%-increase life span over control untreated.
}

ic acid is substrate, takes part in this process (3).

The presented study investigated the effect of reduced folic acid content in the organism, due to deficient diet, on the survival time of mice with L1210 leukemia treated with FU.

\section{Materials and Methods}

\section{Animals and diets}

The experiments were carried out on male mice of $\mathrm{BDF}_{1}$ strain, weighing $18 \sim 20 \mathrm{~g}$ (10 weeks old at the begining of the experiments), obtained from the Institute of Immunology and Experimental Therapy, Polish Academy of Sciences (Wroclaw), quarantained for 7 days after arrival. Mice divided into 2 groups, fed during the whole period of the experiments with two different laboratory diets. Group 1 received a synthetic diet A requirements for protein, fats, carbohydrates, microelements and vitamins, prepared according to Urbanek-Karlowska (4, 5). Diet A contained $2 \mathrm{mg}$ of folic acid per kilogram of diet. Group 
2 was fed with a synthetic diet B, prepared without folic acid.

\section{Antineoplastic effects on L1210 leukemia in mice}

The assessment of antineoplastic activity of FU, was carried out according to the method of Geran et al. (6). L1210 leukemic cells, passaged in DBA/2 mice, were transferred i.p. into $\mathrm{BDF}_{1}$ experimental animals, divided into 2 groups ( $3 \times 10^{5} \mathrm{~L} 1210$ cells per mouse). Prior to the inoculation with leukemic cells, the $\mathrm{BDF}_{1}$ mice had been fed with 2 different synthetic diets for 14 days. The day of inoculation was regarded as the "zero" day of the antileukemic assay. FU was injected i.p. $24 \mathrm{~h}$ after inoculation with L1210 leukemia, as single $80,40,20 \mathrm{mg} / \mathrm{kg}$ doses in two experimental groups fed with different diets. Control mice inoculated with L1210 leukemia in both groups did not receive any drugs. FU (Fluoroblastin) from Farmitalia was used for the assay.

The prolongation of survival time of mice subjected to FU treatment, as compared with control ones, was calculated according to the following formula :

$$
\mathrm{LLS} \%=\left[\frac{\mathrm{MST}_{\mathrm{t}}}{\mathrm{MST}_{\mathrm{c}}}-1\right] \times 100
$$

where ILS\% - prolongation of survival time of treated mice

MST $_{t}$-median survival time of mice in the treated experimental group

$\mathrm{MST}_{\mathrm{c}}$-median survival time of mice in the control, untreated group

ILS\% was used as the criterium of antineoplastic effect. Prolongation of the survival time of treated animals, in comparison with the untreated group, by at least $25 \%$, is an indicator of antineoplastic effect of the used dose of the drug. Median survival time of the animals was calculated according to the following formula :

$$
\operatorname{MST}=\frac{x+y}{2}
$$

where $\mathrm{x}$ - the earliest day when the number of dead animals amounts to $\frac{\mathrm{N}}{2}$

$y$ - the earliest day when the number of dead animals amounts to $\frac{\mathrm{N}}{2}+1$

$\mathrm{N}$-number of animals in the group

\section{Hematological parameters assay}

Erythrocyte and leukocyte counts, as well as he-
Table 1. Effects of FU on the survival of mice with leukemia L1210 after 14 days of folic acid-replete and folic acid-deficient diets.

Folic acid-replete diet A Therapeutics

\begin{tabular}{cccc}
\hline $\begin{array}{c}\mathrm{FU} \\
(\mathrm{mg} / \mathrm{kg})\end{array}$ & $\begin{array}{c}\text { MST } \\
\text { (days) }\end{array}$ & $\begin{array}{c}\overline{\mathrm{X}} \pm \mathrm{SE}^{\mathrm{a}} \\
\text { (days) }\end{array}$ & $\begin{array}{c}\mathrm{ILS} \\
\%\end{array}$ \\
\hline 0 & 8.0 & $8.5 \pm 0.2$ & 0.0 \\
20 & 9.5 & $9.7 \pm 0.3^{*}$ & 18.7 \\
40 & 10.0 & $10.0 \pm 0.4^{*}$ & 25.0 \\
80 & 13.0 & $13.2 \pm 0.3^{*}$ & 62.5 \\
\hline
\end{tabular}

Folic acid-deficient diet B

Therapeutics

\begin{tabular}{cccc}
\hline $\begin{array}{c}\mathrm{FU} \\
(\mathrm{mg} / \mathrm{kg})\end{array}$ & $\begin{array}{c}\text { MST } \\
\text { (days) }\end{array}$ & $\begin{array}{c}\overline{\mathrm{X}} \pm \mathrm{SE}^{\mathrm{a}} \\
\text { (days) }\end{array}$ & $\begin{array}{c}\text { ILS } \\
\%\end{array}$ \\
\hline 0 & 8.0 & $8.5 \pm 0.2$ & 0.0 \\
20 & 8.0 & $8.0 \pm 0.3^{*}$ & 0.0 \\
40 & 8.5 & $8.5 \pm 0.2^{*}$ & 0.0 \\
80 & 9.0 & $9.0 \pm 0.4^{*}$ & 12.5 \\
\hline
\end{tabular}

matocrit and hemoglobin values were determined in the experimental $\mathrm{BDF}_{1}$ mice by means of standard laboratory methods. Blood samples were obtained from the cardiac ventricles of animals in light ether aethylicus anesthesia and collocted into heparinized capillary tubes. Erythrocyte counts were done using a Thome hemocytometer, and leukocyte counts using a Burker hemocytometer. Hemoglobin concentrations were determined by means of the standard cyanmethemoglobin method. Blood samples were collected prior to initiation of the diets, as well as after 14 days of feeding with the synthetic diets. Determination of concentrations of folic acid and vitamin $\mathrm{B}_{12}$ was done by means of the radioisotopic method using: $\mathrm{Ra}$ dioassay Vitamin $\mathrm{B}_{12} /$ Folate (Farmos Diagnostica-Finland).

\section{Statistical analysis}

In all the cases the normality of distribution was checked by means of Kolmogorow-Smirnow test with correction by Lillieforse and equality of variance by means of Fischer's test. As the obtained variances were identical, Student's t-test was used. The pre sumed level of significance was 0.05 .

\section{Results}

Table 1 presents the antineoplastic effects of FU in mice with L1210 leukemia after feeding with syn- 
Table 2. Folate, vitamin $\mathrm{B}_{12}$ levels in plasma and hematological parameters in mice after 14 and 28 days of folic acid-replete $\therefore-z-$ ificient diets

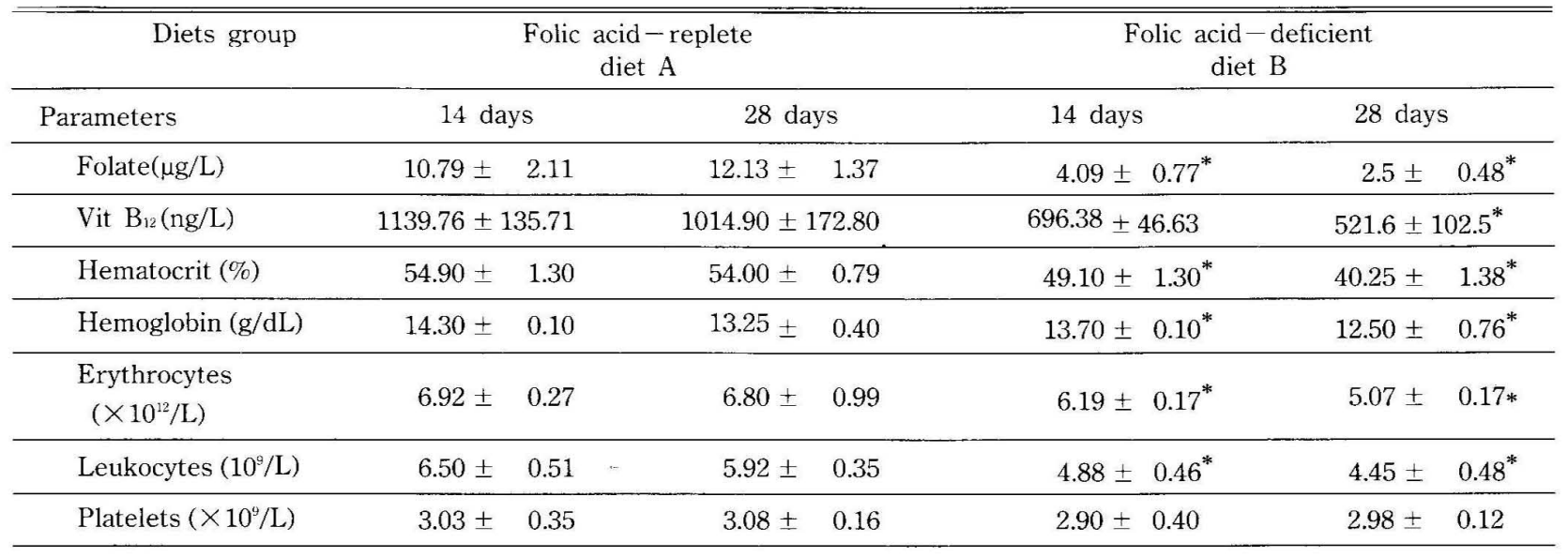

Experimental conditions were as described in Materials and Methods. Six animals in each group. Values are means \pm SE. *Significantly different at $\mathrm{p}<0.05$ between group diet $\mathrm{A}$ and diet $\mathrm{B}$ fed.

thetic diets containing various levels of folic acid.

FU administered to mice inoculated with L1210 leukemic cells after 14-day period of feeding synthetic-replete diet with folic acid content $2 \mathrm{mg} / \mathrm{kg}$ diet caused a prolongation of survival time in comparison with that of control, untreated animals. The increase of survival time was dependent on the administered dose. FU therapy administered to mice inoculated with L1210 leukemia after 14-day period of feeding with synthetic diet without folic acid content using analogous drug doses as those used in the previous group, did not cause significant increase of survival time in any group.

No differences in survival time were found, however, among the groups of untreated mice inoculated with L1210 leukemia fed with various synthetic diets. Table 2 presents the effects of 14-day and 28-day periods of feeding with synthetic diets containing various folic acid levels on selected hematological parameters, as well as on blood serum levels of folic acid and vitamin $B_{12}$ in mice.

Feeding with synthetic diet 8 without folic acid content led to a decrease of hemoglobin, hematocrits, erythrocyte and leukocyte count values. Blood serum folic acid and vitamin $\mathrm{B}_{12}$ levels were reduced in comparison with the values observed in the blood serum of mice receiving the diet $\mathrm{A}$ which met the animals requirement for folic acid.

\section{Discussion}

From the presented study it follows that the synthetic diet prepared without the addition of folic acid caused significantly lower blood serum folic acid levels, reduction of vitamin $\mathrm{B}_{12}$ level, anemia, as well as lowered leukocyte count. The antineoplastic effect of FU on L1210 leukemia was in that group of mice weaker than the effect of $\mathrm{FU}$ in mice receiving synthetic diet which met their folic acid requirement. FU exerts its cytotoxic effect mainly by two mechanisms inhibition of RNA synthesis by binding of FUTP (FU metabolite), as well as inhibition of DNA synthesis by depletion of dTMP pool, which results from the inhibition of thymidylate synthase another metabolite of FU, FdUMP. Binding of FdUMP to the enzyme requires the activity involvement of tetrahydrofoliane cofactor, for which folic acid is the substrate $(3,7,8)$. Depletion of the tetrahydrofoliane cofactors pool may be expected as results of decreased availability of folic acid. FU monotherapy has been routinely used in the treatment of patients with advanced stages of carcinoma of the colon and rectum with diagnosed metastases. The low efficacy of the therapy, limited to only $15 \sim 20 \%$, is due mainly to the advanced stages of the disease (9). Deficient nutrition of such patients may lead to the deficit of folic acid in the organism and consequently to lower cytotoxic potency of $\mathrm{FU}(8)$. In malignancies, folic acid requirement is increased (10). Until quite lately it was believed that folate deficiency might be beneficial in patients and animals with neoplasms, while administration of larger quantities of folic acid might have cocarcinogenic effect (11). But now, however, a considerable evidence has been accumulated, which indicates that normal cells showing deficiency of this vitamin are more susceptible to neoplastic transfor- 
mations (11, 12, 13). Thus determination of folic acid levels in the neoplastic patients prior to administration of FU seems plausible. Folic acid supplement might increase the therapeutic efficacy of FU.

\section{Reference}

1. Koszarowski, T. (1985). Onkologia kliniczna, pp 204-222, PZWL, Warszawa.

2. Mini, E., Coronello, M.,Carotti, S., Gerli, A., Pesciullesi, A., Morosori, B.A., Mazzei, T., Periti, P. and Bertino, J.R. (1990) Biochemical modulation of fluoropyrimidines by antifolates and folates in an in vitro model of human leukemia. J. Chemotherapy 2 (Supp. 1), 17-27.

3. Myers, CH.E. (1981) The pharmacology of the fluoropyrimidines. Pharmacol. Rev. 33, 1-15.

4. Urbanek-Karlowska, B. (1976) Wplyw niedoborów bialkowych u szczurów na toksycznośc kaptanu. Roczn. P.Z.H. $26,137-141$.

5. Graczyk, J. (1980) Acute toxicity of methotrexate and cyclophosphamide in underfed mice. Brom. Chem. Toksykol. 13, 111-119.

6. Geran, R.J., Greenberg, N.II., Macdonaod, M.M., Schumacher, A.M. and Abbott, B.J. (1972) Protocols for screening chemical agents and natural products against animals tumors and other biological systems (third edition). Cancer Chemother. Rep. 3, 1-103.

7. Santi, D.V., Mc Henry, C.S. and Sommer, H. (1974) Mechanism of interaction of thymidylate synthase with 5fluorodeoxyuridylate. Biochemistry 13, 471-481.

8. Graczyk, J. (1992) The influence of folate and antifolate on the cytostatic activity of fluoropyrimidines. Post. Hig. i Med. Dośw. 46, 143-158.

9. Davis, H.L. (1982) Chemotherapy of large bowel cancer. Cancer 50, 2638-2646.

10. Wartanowicz, M. (1993) Foliany-aktualny stan wiedzy (Folates-up date). Zywienie czlowieka i metabolizm 20, 139-148.

11. Rosen, F. and Nichol, C.A. (1962) Inhibition of the growth of an amethopterin refractory tumor by dietary restriction of folic acid. Cancer Res. 22, 495-500.

12. Baggott, J.E., Vaughn, W.H., Juliana, M.M., Eto, I., Krumdieck, C.L. and Grubbs, C.J. (1992) Effects of folate deficienjcy and supplementation on methylnitrosourea induced rat mammary tumors. J. Natl. Cancer Inst. 84 (22) $1740-$ 1744.

13. Eto, I. and Krumdieck, C.L. (1986) Role of vitamin $B_{12}$ and folate deficiency in cancerogenesis. Adv. Exp. Med. Biol. 206, 293-297. 